\title{
Qualitative Study: \\ The Organizational Management for Academic Character Building of the AKBARA Polytechnic of Surakarta Member
}

Titis Wahyuono, Tri Wuryanto, Syarifah

Politeknik AKBARA Surakarta, Indonesia

Corresponding email: syarifah@akbara.ac.id

\begin{abstract}
:
Various facts and phenomena of human moral degradation in higher education both lecturers, college students, and managers have occurred over time because of the rapid mordenization (Setiawati, 2012). Therefore, researchers are interested to know the qualitative study to find out how the social phenomenon in collage today so that it will bring up important points in the effort to create and build the character of college students. The approach used in this research is qualitative approach. The population in this study is the entire staff of AKBARA Surakarta Polytechnic. The sample in this study was 32 respondents using total sampling techniques. Research data is the main data by conducting interviews to all staff of AKBARA Surakarta Polytechnic. Then a scientific study was carried out from the source of the library which eventually obtained conclusions from problem solving about the research carried out. Data analysis techniques used are qualitative study research phenomena. The results showed that the characteristics of respondents as the highest sex in women was $51.5 \%$, seen in terms of age in the age range $21-35$ year olds with a percentage of $75 \%$, and post-graduate education with a percentage of $48.5 \%$. It is crucial to get a character education. This aims to strengthen morals and praiseworthy qualities for college students (in this case, college students) because intelligence in education is not enough without strong moral and character provisions. This is where the importance of character education. An attitude of empathy is one of the character qualities that can change the world. Polytechnic AKBARA concern about those activities in building the student's character. The management initiated the CAKRA Akbara, which consists of Competent, Toughness, and Character.
\end{abstract}

\section{Keywords:}

Academic character building, implementation, behavior

\section{INTRODUCTION}

Various facts and phenomena of human moral degradation in higher education both lecturers, college students, and managers have occurred over time because of the rapid mordenization (Setiawati, 2012). Implementation of Law 20th on 2018 is strengthening character education in polytechnic, namely the need for an assessment of how strong the influence between character education, education and foreign to create a characteristic college climate. (M F Ma'ruf, 2020)

From birth to adulthood, there are tasks as individuals in living the phases of life in order to successfully live life, including in students who undergo the process of education in higher education. Based on this, universities must prepare ready-to-use graduates in the global era, to improve competitiveness at the international level. Students are educated from the beginning of college with a variety of good behavior provisions. In order to achieve 
this, character education is needed. Character education refers to education that includes the values of Pancasila, ethics, morals, and character education.(Dharmawan, 2014)

In addition, nowadays we find many universities that only demand academic ability in students, among others, the demands to excel with the best GPA, have a good understanding of theoretical science, do college assignments correctly and on time, and other academic demands. However, there are not many educational institutions that provide a focus on aspects other than academics. This document is prepared as a learning strategy that is not only oriented to academic aspects or competencies but also needs to prepare learning strategies that produce students who are resilient and dare to answer global challenges by not only capitalizing on good academic ability but also with courage and physical toughness.(Dwijonagoro et al., 2019)

Today, there are many cases of student crimes such as vandalism, violence, and intolerance and radicalism. This is against the backdrop of the character education crisis. In addition, we often find many clever people who abuse their intelligence to commit criminal offences, such as being a corruptor or a terrorist. Thus, character strengthening becomes important for students for the birth of the next generation of the nation that can compete in the global world.(Susilo \& Wulansari, 2019)

Therefore, researchers are interested to know the qualitative study to find out how the social phenomenon in collage today so that it will bring up important points in the effort to create and build the character of college students.

\section{THEORITICAL REVIEW}

\section{Character Education}

Strengthening character education in formal education institutions vary widely. However, the government, in this case the ministry of education and culture has issued a regulation or called permendikbud number 20 of 2018 on Strengthening Character Education in formal education units. This regulation serves as a guideline for formal education units in the implementation of character education in their respective environments. (Moh Farid Ma'ruf, 2020)

One of the institutions of the education unit formal in surakarta city named Polytechnic AKBARA Surakarta. It is a polytechnic-level formal college that has a semimilitary concept. As the name implies, this college also has a characteristic that distinguishes it from other formal campuses especially when it it is about planting character education.

Character is an element of personality that is reviewed ethically or morally. The character refers to a series of attitudes, behaviors, motivations and skills as a manivestasi of human values and moral capacity in the face of adversity. Characters contain distinctive values (e.g., good values, willing to do good, real good life and have a good impact on the environment) that are enfixed in themselves and manifested in behavior. (Sriwilujeng, 2017)

The character feels from the Greek meaning to mark or mark and focus on how to apply the value of good in the form of actions or behaviors (Zubaedi, 2015). And according to the Ministry of National Language Center said "the character is innate, heart, soul, personality, ethics, behavior, personality, nature, behavior, temperament, character". Therefore, character terms are associated and intended with ethical terms, morals, and or values related to the moral power of postive connotations rather than neutral. While the definition according to the great Dictionary of Indonesian in 
(Purwanto, 2014) "character is the psychiatric qualities of morality or ethics that distinguish one from another".

According to Purwanto (2014), "the behavior of a person of character is essentially the embodiment of the function of psychological totality that encompasses the entire potential of human individuals (cognitive, effective, conative and psychomotor) and the function of totality in the context of interaction (in families, educational units and communities) and the continuity of for the rest of my life".

Character configurations in the context of psychological and sociocultural totality can be grouped as described as follows:

\begin{tabular}{lll}
\hline No & Scope of Character Education & $\begin{array}{l}\text { Context of Totality of Psychological and } \\
\text { Socio-Cultural Processes }\end{array}$ \\
\hline 1. & $\begin{array}{l}\text { Olah Hati } \\
\text { (Spiritual and Emotional } \\
\text { Development) }\end{array}$ & $\begin{array}{l}\text { Faith and Piety, honest, trustworthy, fair, } \\
\text { responsible, empathetic, courageous, risk- } \\
\text { taking, abstinent, willing to sacrifice, and } \\
\text { patriotic. }\end{array}$ \\
2. $\quad \begin{array}{l}\text { Olah Pikir } \\
\text { (Intellectual Development) }\end{array}$ & $\begin{array}{l}\text { curious, open-minded, productive, science- } \\
\text { oriented, and reflective } \\
\text { Clean and healthy, disciplined, }\end{array}$ \\
3. Olah Raga dan Kinestetik & $\begin{array}{l}\text { (Physical and Kinestetic } \\
\text { sportsmanship, tough, reliable, resilient, } \\
\text { friendly. }\end{array}$ \\
Development) & $\begin{array}{l}\text { Olah Rasa dan Karsa } \\
\text { (Affective and creativity }\end{array}$ & $\begin{array}{l}\text { Friendly, respectful, tolerant, caring, helpful, } \\
\text { gotong royong, nationalist, cosmopolitan, } \\
\text { public interest, proud to use Indonesian } \\
\text { language and products, dynamic, hard work }\end{array}$ \\
& and work ethic \\
\hline
\end{tabular}

Source: Character Education Implementation Handbook

2. Organizational Management

Globalization challenging blows the life of university, tertiary educational institution that has main activity in high educational conversation with academic activity which commonly has universal concepts and adoptive ability in order to balance with the condition and Indonesia situation. Now days, tertiary educational institution is focused on the real big transformation era and it cannot be denied anymore that the university must accept it if want surviving, striving, and developing.(Mulyono, 2016)

Advanced universities, in fact, are not enough just play an active role in answering the challenges of the needs of industry, business and society today, but should play a proactive role in engineering the needs of the community that is expected to occur in the future. Thus, the reciprocal relationship between universities and the user community (government, business, industry and other community institutions) must be established in order to occur conformity, harmony and sustainability of the availability of labor needed.

Making universities able to meet the demands of the community (achieve external efficiency) and at the same time support the development of community needs in the future, universities should make themselves efficient in organization and activities 
(internal efficiency). Kemenristekdikti stipulates the policy that in the field of higher education must be achieved improvement on seven objectives, namely:

a. Relevance of goals and objectives.

b. Efficiency.

c. Productivity.

d. Effectiveness.

e. Accountability.

f. System management.

g. Academic atmosphere or organizational health.

Experts and practitioners of higher education concluded that there are several ideas that can be believed to be efficient in the management of universities today, among others:

a. The organization of universities today, must be flexible, not nationally standardized, not rigid, not bureaucratic, does not require a high hierarchy ladder. It should be designed in the form of a matrix organization, open and uphold the nature of education. Expand authority by profession and face authority under the law. Relationships are collegial rather than hierarchical.

b. Leaders of universities should be professionals in management or university administration, in addition to having to be academically qualified or high intellectual level wherever possible should be predicated as a doctor or professor. Elements of university leadership must be assisted by elements of academic implementation (teaching, research and community service) who are also qualified professionals. Academic executor, need to predicate professors, doctors in their fields. Elements of administrative implementation, absolutely educated, trained in the administration of ICT-based universities. The absolute leadership is supported by the planning and evaluation bureau which is not an administrative executor but a professional in the field of college development planning.

c. For quality control of national institution accreditation of universities, it needs to be activated and managed professionally according to the field of science.

d. Binding, bureaucratic, rigid, centralistic legislation needs to be reviewed and provide opportunities for universities to grow in accordance with the environment and ability level.

e. Coaching lecturers, need to be designed and implemented continuously. High quality permanent lecturers must be maintained, nurtured, supported by sufficient costs and facilities, in order to concentrate the concentration of work on their duties.

f. Teaching management skills (managing classes, designing teaching programs, assessing learning outcomes to develop teaching methods and techniques, controlling teaching and learning processes, using learning resources, etc.) must be possessed in order to improve creativity and quality of learning.

g. For quality control of college management it is necessary to make effective the role of the board of trustees, college senate, college development planning body and establish close cooperation with professional associations, higher education consortiums, absolutely must function and be organized based on disciplines by experienced administrators.

h. College funding needs to be increased.

i. The opening of new universities, needs to be controlled based on academic requirements and on the calculation of priority fields of science. 
j. Organizing foundation, it is necessary to clarify the status of the legal entity.

(Developed from Mansoer, 1994)

\section{RESEARCH METHOD}

The approach used in this research is qualitative approach. The population in this study is the entire staff of AKBARA Surakarta Polytechnic. The sample in this study was 32 respondents using total sampling techniques. Research data is the main data by conducting interviews to all staff of AKBARA Surakarta Polytechnic. Then a scientific study was carried out from the source of the library which eventually obtained conclusions from problem solving about the research carried out. Data analysis techniques used are qualitative study research phenomena.

Qualitative research is a systematic investigation into social phenomena in a natural setting. These phenomena can include, but are not limited to, how people experience aspects of their lives, how individuals and/or groups behave, how organizations function, and how interactions form relationships. Research phenomena can be any problem, problem, or topic chosen as the subject of investigation. This phenomenon may come from the practical world of affairs, theoretical discipline, or personal experience or insight. For this research will be centered on how appropriate management in finding startegi foster character education to students at the AKBARA Polytechnic Surakarta.

\section{RESULTS AND DISCUSSION}

\section{Characteristics of Respondents}

This research was conducted in December 2020 to the staff of Polytechnic AKBARA Surakarta. Staff of Polytechnic Akbara Surakarta was 32 people consists of lecturers and education personnel consisting of the student section, public relations and cooperation laboratory and library department, laboratory staff, student staff, information and technology staff, public relations and cooperation staff, library staff, staff and general department, student staff, staffing staff, administrative staff, finance department, academic staff and polytechnic leadership AKBARA Surakarta.

Table 1. Distribution of respondents

\begin{tabular}{lcc}
\hline Characteristic & $\begin{array}{c}\text { Frequency } \\
\text { (n) }\end{array}$ & $\begin{array}{c}\text { Percent } \\
\text { (\%) }\end{array}$ \\
\hline 1. Gender & & \\
Man & 16 & 48.4 \\
Women & 17 & 51.5 \\
2. Age & & \\
$21-35$ & 24 & 75 \\
$36-50$ & 5 & 15.6 \\
$>50$ & 3 & 9.4 \\
3. Education & & \\
Undergraduate & 6 & 18.2 \\
$\quad$ Bachelor Degree & 10 & 30.3 \\
Post Graduate & 16 & 48.5 \\
Master & 1 & 3.0 \\
Total & 33 & 100.0 \\
\hline
\end{tabular}

(Primary data, 2020) 
In the gender of staff, a balanced data was obtained between the number of men and women with a high gain in women of $51.5 \%$. Over viewed characteristics of the respondents age, the frequency distribution of the staff of Polytechnic AKBARA Surakarta, the highest cure rate at the age of $21-35$ years is $75 \%$. According to the characteristics of the respondents the type of education, the highest number of the staff of Polytechnic AKBARA Surakarta post graduate is $48.5 \%$.

\section{Qualitative Study of Character Education}

a. Is character education important in college? Explain briefly!

Character education is essential for us, especially for children who are still in the world of education. Character education in education is used as a forum or process to shape a child's personality to become the right person. Character education is education carried out to shape a person's personality to become the right person. In education, character education is crucial for college students, for their provisions when they are already working.

The character of an individual is formed since he was a child due to genetic and environmental influences. The process of character building, whether consciously or not, will affect the way the individual sees himself and his environment and will be reflected in his daily behavior. Universities, as higher education institutions, are one of the most critical resources.

So for college students, it is crucial to get a character education. This aims to strengthen morals and praiseworthy qualities for college students (in this case, college students) because intelligence in education is not enough without strong moral and character provisions. When college students enter the community, there will be no misuse of the knowledge learned during school.

b. What is the importance of having a character education in college?

The desire to become a nation that is democratic, free from corruption, collusion, and nepotism (KKN), respects and obeys the law are some of the characteristics of a nation that is desired in society's life, nation, and state. However, reality shows the opposite phenomenon.

Another thing that is common among college students and college students is in the form of delinquency. Some of them are brawls between college students and between college students. In some significant cities, student brawls have become a tradition and form a fixed pattern so that between them, they form sworn enemies. Brawls are also often carried out by college students, as is done by a group of college students. Other forms of delinquency committed by college students are drinking alcohol, promiscuity, and drug abuse, leading to depression and even HIV/AIDS. Another phenomenon that promotes college students and educational institutions' image is the rise of student gangs and motorbike gangs. Their behavior often leads to violence (bullying) that disturbs the community and even criminal acts such as bullying, persecution, and even murder. All of the student's negative behaviors, as mentioned earlier, and university college students indicate a moderately severe fragility of character, one of which is caused by not optimal character development in educational institutions and unsupportive environmental conditions.

Thus, it is necessary to find the best way to build and develop the character of the Indonesian people and nation to have a good, superior, and noble character. The 
right effort for that is through education because education has an essential and central role in developing human potential, including mental potential. Through education, it is hoped that a transformation can occur that can develop positive characters and change the character from bad to good. Ki Hajar Dewantara firmly stated that education is an effort to promote the growth of character (inner strength, character), mind (intellect), and the child's body. So it is clear, education is the primary vehicle for developing good character. This is where the importance of character education.

c. What is the importance of the environment on character education building?

The environment is unity with all space, power, state, and living things, including humans and behavior that affect the sustainability of livelihoods and the welfare of humans and other living things (Law no. 23 of 1997). Environmental recognition activities are expected to have a significant and permanent impact on the formation of children's character in caring for the environment and fostering empathy and awareness of oneself as social beings.

Character building in campuses, especially in universities (PT), is motivated by the rampant deviations that occur in the public sphere. Value disorientation and disharmony at the level of people's lives are often found.

In student affairs, all relevant policymakers are faced with the problem of returning noble values to each student. So that college students are not only smart, knowledgeable, and superior, but also responsible and ethical. With characterbuilding education, it is hoped that each graduate will have a more empathetic attitude. An attitude of empathy is one of the character qualities that can change the world.

d. What is the strategy to build AKBARA Polytechnic college students' character?

Character building can be done through training activities. Character building training includes providing material on leadership, organization or management, skills related to developing interests and talents or interpersonal skills, and academic culture.

AKBARA Polytechnic concern about those activities in building the student's character. The management initiated the CAKRA Akbara, which consists of Competent, Toughness, and Character. Each of them is described below:

1) Competent means knowing; in power (decide, determine) something; have authority. All Akbara Polytechnic college students must be competent. This is adjusted to the Graduate Competency Standards, where all criteria regarding the qualifications of graduate abilities, including attitudes, knowledge, and skills, can be adequately mastered.

2) Toughness means hard to beat; strong; reliably. Unyielding person (tough) is a term for a person who does not feel weak against something that happens to him. They consider something that happened in a positive light. A person becomes strong basically because he is mentally healthy. A person becomes weak because he is mentally weak. The formation of this challenging personal trait begins with the optimism that surrounds the person's mindset.

3) The notion of character is "innate, heart, soul, personality, character, behavior, personality, character, character, temperament, character." Meanwhile, having character is having a personality, behaving, having character, having character, 
and having character. The person with this character, several traits need to be nurtured, namely: loving God and all of his creation; to be responsible; disciplined; independence; good; humble; confident; creative and hard-working; leadership and justice; tolerance; peace; unity; honesty; wisdom; respect; polite; generous; helpful; cooperation; cooperation; and it's kind.

e. What is the most effective way to create good habits at AKBARA Polytechnic?

Along with the Merdeka Campus implementation, Akbara Polytechnic has developed many activities that also support Cakra Akbara. Activities organized by the Akbara Polytechnic to oversee the Cakra Akbara include holding internships and practicum in the curriculum, forming student activity units (UKM) to facilitate student interest talents, and student checking apples all college students to take part in karate activities with a schedule accordingly.

The entire series of activities is carried out gradually and continuously. This aims to make new habits for college students to equip college students to be competent, tough, and have a character who can become role models in their new environment after graduating from Akbara Polytechnic.

The activities held did not only come from routine campus activities but also student initiations. This makes Akbara Polytechnic more diverse in its activities. Activities held at Akbara Polytechnic are semi-military. Thus, the military atmosphere was felt every day. Furthermore, in monitoring Akbara Polytechnic activities entire implementation, a standard and the written rule is needed. The regulations are contained in the Akbara Polytechnic Code of Conduct Document. The supervision is submitted to the Code of Ethics Council so that deviations that will arise can be avoided.

f. What are the difficulties faced by the member of Akbara Polytechnic in implementing the character education?

The implementation of character education has its problems, namely the inconsistency between the concept of character education, which aims to restore the nation's culture and character, which is increasingly deteriorating with the reality at hand. Good character values are instilled at the university level, not supported by social, environmental conditions that exemplify conflicting values.

\section{CONCLUSION}

The results showed that the characteristics of respondents as the highest sex in women was $51.5 \%$, seen in terms of age in the age range 21-35 year olds with a percentage of $75 \%$, and post-graduate education with a percentage of $48.5 \%$.

1. It is crucial to get a character education. This aims to strengthen morals and praiseworthy qualities for college students (in this case, college students) because intelligence in education is not enough without strong moral and character provisions.

2. Education is the primary vehicle for developing good character. This is where the importance of character education.

3. An attitude of empathy is one of the character qualities that can change the world.

4. AKBARA Polytechnic concern about those activities in building the student's character. The management initiated the CAKRA Akbara, which consists of Competent, Toughness, and Character.

5. Activities held at Akbara Polytechnic are semi-military. Thus, the military atmosphere was felt every day. Furthermore, in monitoring Akbara Polytechnic activitie's entire 
implementation, a standard and the written rule is needed. The regulations are contained in the Akbara Polytechnic Code of Conduct Document. The supervision is submitted to the Code of Ethics Council so that deviations that will arise can be avoided.

\section{BIBLIOGRAPHY}

Dharmawan, N. S. (2014). Implementasi Pendidikan Karakter Bangsa Pada Mahasiswa Di Perguruan Tinggi. Makalah Disampaikan Pada Pembinaan Pendidikan Karakter Bagi Mahasiswa PTS Di Lingkungan Kopertis Wilayah VIII.

Dwijonagoro, S., Meilawati, A., Nurhidayati, N., \& Wulan, S. H. (2019). Character Education in Banjaran Bima Play and Its Implication in Education. Jurnal Pendidikan Karakter. https://doi.org/10.21831/jpk.v9i2.24981 access on 28th Dec 2020 at 09.00 pm

Ma'ruf, M F. (2020). Implementasi Permendikbud Nomor 20 Tahun 2018 Tentang Penguatan Pendidikan Karakter. Jurnal Pendidikan Dewantara: Media ..., 6(1), 90-101. access on $20^{\text {th }}$ December 2020 at $08.00 \mathrm{pm}$

Ma'ruf, Moh Farid. (2020). Implementasi Permendikbud Nomor 20 tahun 2018 tentang Penguatan Pendidikan Karakter. Jurnal Pendidikan Dewantara: Media Komunikasi, Kreasi Dan Inovasi IImiah Pendidikan, 6, 93-102. https://jurnal.stkippgritrenggalek.ac.id/index.php/dewantara/article/view/56 access on $20^{\text {th }}$ Desember 2020 at $08.00 \mathrm{pm}$

Mansoer, H. (1994). Menuju Manajemen Perguruan Tinggi yang Efisien. Majalah IImiah Kampus.

Mulyono. (2016). Tantangan global dan upaya menuju manajemen perguruan tinggiyang efisien. Jurnal MPI, 1. http://repository.uin-malang.ac.id/5985/1/5985.pdf access on 20th December 2020 at $08.45 \mathrm{pm}$

Purwanto, N. (2014). Pengantar Pendidikan. Graha Ilmu. https://adoc.pub/pengantarpendidikan-oleh-nanang-purwanto-spd-mpd-hak-cipta-.html access on 20th december 2021 at $08.00 \mathrm{pm}$

Setiawati, L. (2012). Efektivitas Pengembangan Manajemen Pendidikan Tinggi. Jurnal Penelitian Pendidikanl Vol, Vol. $13 \quad$ No, 1-16. http://jurnal.upi.edu/file/Linda_setiawati.pdf access on 20th December 2020 at 08.45 $\mathrm{pm}$

Sriwilujeng, D. (2017). Panduan Implementasi Penguatan Pendidikan Karakter (H. E. (ed.)). Erlangga.

Susilo, A., \& Wulansari, R. (2019). Kuliah Lapangan Sejarah sebagai Penguatan Pendidikan Karakter Mahasiswa STKIP PGRI Lubuklinggau. Criksetra: Jurnal Pendidikan Sejarah. https://doi.org/10.36706/jc.v8i2.9369 access on 20th December 2020 at 08.45 pm

Zubaedi. (2015). Desain Pendidikan Karakter: Konsep Aplikasinya dalam Lembaga Pendidikan.

Kencana.

https://books.google.co.id/books?id=fje2DwAAQBAJ\&printsec=frontcover\&hl=id\&sourc $\mathrm{e}=\mathrm{gbs} \_g$ e_summary_r\&cad=0\#v=onepage\&q\&f=false access on 20th December 2020 at $08.45 \mathrm{pm}$ 